International Journal of Physical Sciences and Engineering
Available online at http://sciencescholar.us/journal/index.php/ijpse
Vol. 2 No. 1, April 2018, pages: $35 \sim 46$
e-ISSN : 2550-6943, p-ISSN : 2550-6951
http://dx.doi.org/10.29332/ijpse.v2n1.89

\title{
Value Engineering Approach for Construction Materials Selection of Irrigation Drainage
}

(Case Study on Project of DAS Irrigation Drainage Improvement at Cengcengan River in Gianyar)

Made Sudiarsa a , Wayan Sudiasa ${ }^{\text {b }}$, Ketut Sutapa ${ }^{c}$

Article history: Received 8 August 2017, Accepted in revised form 10 January 2018, Approved 10 February 2018, Available online 16 February 2018

Correspondence Author a

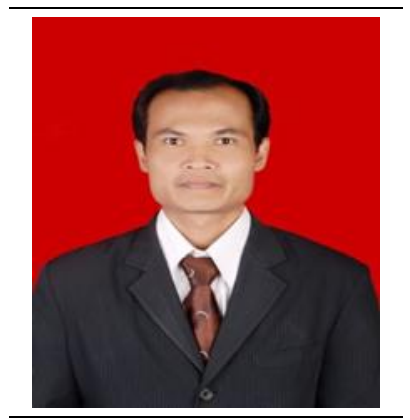

Keywords

Construction design; Construction materials; Cost savings;

Function;

Value engineering;

\begin{abstract}
In this globalization era, many alternative choices of construction materials. The limited funds available make engineers have to think creatively to choose materials used in order to obtain the cost as efficiently as possible. There are many ways to do the cost efficiency of the project, one of them by doing value engineering. The construction design selection is very important to do because it can show the project quality, as well as produce the development with an efficient and optimal cost. The value engineering approach in the construction field is an organized and creative approach aimed at identifying unnecessary costs. These unnecessary costs are costs that do not provide quality or usability/functionality. The value engineering application is to construct projects has considerable potential savings from the project budget. This study aims to obtain cost savings made during the design phase and irrigation drainage project implementation. The scope of the study in the present study is the wall project on the DAS irrigation drainage improvement at Cengcengan River in Sukawati, Gianyar. This analysis uses the steps of value engineering plan, i.e., information, creative, analysis, development, and recommendation steps. Whereas, the criteria used to evaluate the components/systems included aspects of cost, quality, implementation time, methods, mobilization, availability, and aesthetics. In this study, four alternatives will be analyzed, i.e., alternative one using the river stone, alternative two conventional concrete K225, alternative three cycloof concrete and alternative four precast L shape. Regarding the analysis that has been conducted alternative four is the best alternative by using precast $\mathrm{L}$ shape which is used in irrigation drainage project using zero-one method. The cost savings obtained after replacing the stone masonry with precast $L$ shape 20 years old is IDR. 23,754,327,910 with time savings of precast $\mathrm{L}$ shaped mounting work for 490 days.
\end{abstract}

a Department of Civil Engineering, Bali State Polytechnic, Indonesia

b Department of Civil Engineering, Bali State Polytechnic, Indonesia

c Department of Civil Engineering, Bali State Polytechnic, Indonesia 
e-ISSN: 2550-6943, p-ISSN: 2550-6951 @Copyright 2018. The Author. SS Journals Published by Universidad Técnica de Manabí. This is an open-access article under the CC BY-SA 4.0 license

(https://creativecommons.org/licenses/by-sa/4.0/) All rights reserved.

\section{Contents}

Abstract

1. Introduction

2. Research Method

36

3. Results and Analysis

4. Conclusion

Acknowledgements

References

\section{Introduction}

The construction project is a series of interrelated activities to achieve a specific purpose (building/construction) within a certain time, cost and quality. Construction projects always require resources, i.e., human, materials, machines, methods, money, information, and time. In a construction project, there are three important things included time, cost and quality (Kerzner, 2006). One of the construction project activities is the irrigation drainage construction.

In this globalization era, many alternative choices for construction materials. The limited funds available make engineers have to think creatively to choose materials used to obtain the effective cost as possible. There are many ways to do the cost efficiency of the project, one of them by doing value engineering (Soeharto, 2001). Value Engineering is a systematic approach to obtain optimal results of any costs incurred in a creative effort event to analyze functions by removing or modifying unnecessary price increases in the process of financing the construction, operation or execution, maintenance, tools replacement, and others (Dell'Isola, 1974). Value engineering analysis method has advantages a systematic effort, neat, and organized approach in analyzing the subject matter value to the function or its usefulness but still consistent to the need for appearance, realities, quality, and the project maintenance.

Value engineering approaches are conducted to find alternatives or ideas aimed at generating better or lower costs than previously planned prices with functional and work quality constraints. This ensures that a responsible work outcome can be performed. This value engineering approach is carried out on irrigation drainage, wherein the physical construction of the old-fashioned irrigation, i.e., with river stone has many weaknesses. Therefore, alternative construction materials are sought in researching cost-saving opportunities without compromising overall construction performance, which would benefit all parties involved.

\section{Research question}

Based on the above background then it can be formulated some problems included:

a) What is the best material alternative to replace the initial design of the irrigation drainage project?

b) How much cost savings and time after the analysis with value engineering method?

\section{Aims}

The aims are to be achieved in the present research as follows:

a) To find the best material alternative to replace the initial design of the irrigation drainage project

b) To know cost savings and time after the analysis with value engineering method

\section{Research significance}

The research significance in the present study included:

a) Overview the alternative materials that can be used in the application of value engineering to plate components in accordance with the value engineering criteria that must be effective and efficient. 
b) Illustrates the cost savings or cost saving of the alternatives used in the construction.

\section{Research Methods}

The method is chosen in conducting the research is a descriptive evaluative. The research is intended, i.e., research that is conducted on an object systematically to get the facts and the object nature under study. Types and data sources

Data is needed for this research included:

a) Primary data

Primary data is data obtained through direct observation in the field. It is obtained through interviews with respondents (suppliers) in the form of material price data, productivity.

b) Secondary data Secondary data is data obtained by citing existing data through resource persons in the project. Data is in the form of project viewing, cost-saving plan and work plan and terms.

\section{Research procedure}

a) Information. At this stage, the building identification will be in value engineering. It contains general information, design criteria, and functions of the project item section to be analyzed.

b) Creative. A search for alternatives will be used to replace the work items system that has been planned. Unlike the alternatives can be made to substances/materials as well as designs rather than lower structural work items that will be value engineering.

c) Analysis. Calculates a value/work item cost with the offered design alternatives. In calculating the cost can be reviewed regarding substances/materials, labor, time, and work items dimensions. In this stage, convey the contents by using the zero-one method.

d) Recommendation. Provide recommendations for what is conducted in the previous stage, which can be either evaluation or potential value of the highest/greatest savings then summarized into one into a table.

\section{Results and Analysis}

a) Information Stage

Project information data will be analyzed by value engineering:

Project name : Improving DAS irrigation drainage, Cengcengan River, Sukawati Subdistrict, Gianyar Regency.

Project location : DAS Cengcengan River, Sukawati Subdistrict, Gianyar Regency.

Project owner : Official Bina Marga and Drainage, Gianyar Regency.

Project function : Irrigation drainage.

Length : : $3.964,453$ meters

Project value : IDR. 9,058,279,790

The project is implemented two types of irrigation drainage construction included:

a) River stone installation
Length
: $1.234,87 \mathrm{~m}^{2}$
Cost
: IDR. $1.594 .340,694$
Plastering work : IDR. $35.660 .269,80$
Broadcast work : IDR. 59.160.997,59
b) Precast L shape installation
Length
: 3,184.30 m
Cost
: IDR. 5.100.356.515

Working floor concrete work: IDR. 404.140.762,06

In the information stage, several ways are used to identify the work to be done value engineering, i.e., cost model, and function analysis.

Sudiarsa, M., Sudiasa, W., \& Sutapa, K. (2018). Value Engineering Approach for Construction Materials Selection of Irrigation Drainage. International Journal Of Physical Sciences And Engineering (IJPSE), 2(1), 35-46. 


\section{Cost Model}

The cost model is a part of work that is grouped according to each project element. It can be seen in the following figure 1 .

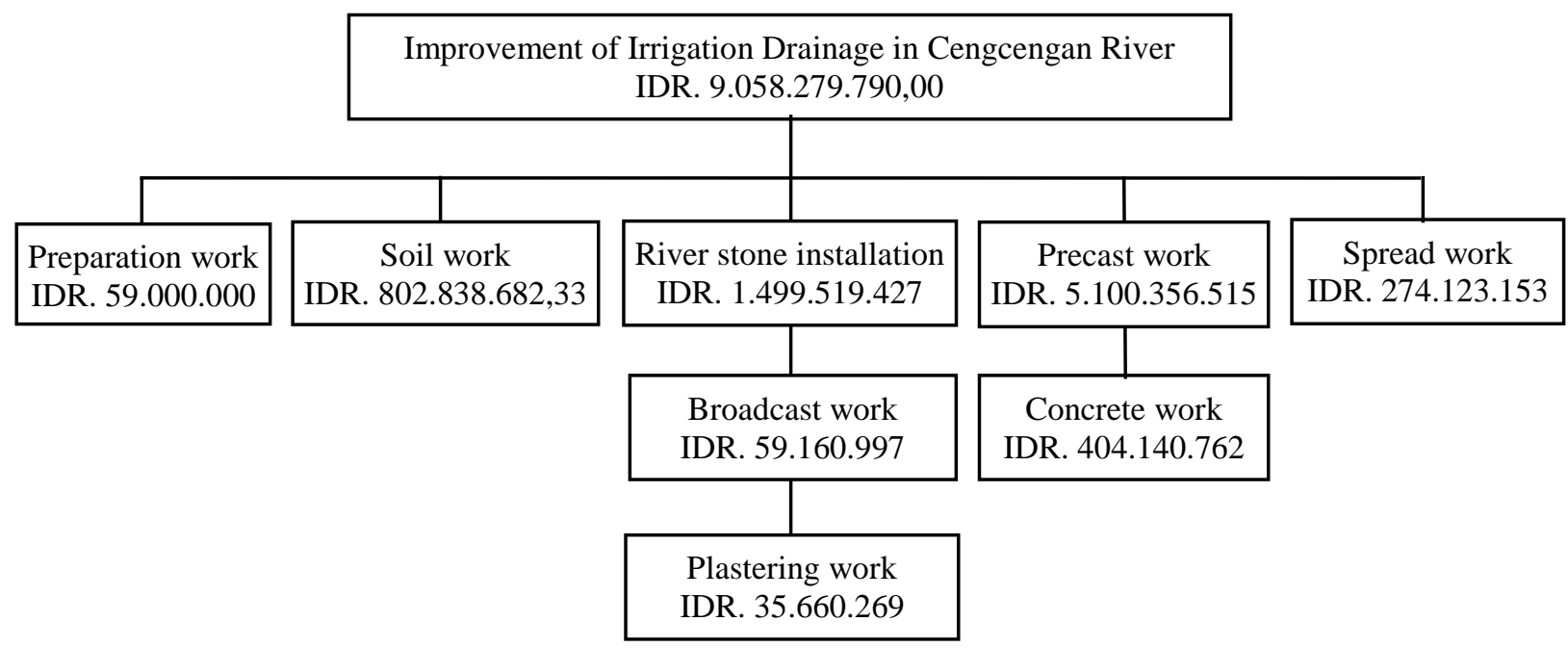

Figure 1. Cost Model.

\section{b) Functional Analysis}

Functional analysis is the main basis in value engineering. It distinguishes value engineering from other cost-saving techniques. This analysis assists the value engineering team in determining the lowest cost required to perform key functions and support functions and identify costs that can be reduced or eliminated without affecting performance or product constraints. The product/building function is thoroughly determined first before determining its elements function.

Table 1

Analysis of drainage irrigation project function

\begin{tabular}{lll}
\hline \multicolumn{1}{c}{ Project Item } & \multicolumn{1}{c}{ Function } & \multicolumn{1}{c}{ Type } \\
\hline \multirow{3}{*}{$\begin{array}{l}\text { River stone installation on } \\
\text { drainage irrigation }\end{array}$} & Streaming Water & Primary \\
\cline { 2 - 3 } & Protecting Plants & Secondary \\
\cline { 2 - 3 } & Dividing Water & Secondary \\
\cline { 2 - 3 } & Draining Water & Secondary \\
\cline { 2 - 3 } & Reducing Flow & Secondary \\
\hline
\end{tabular}

\section{c) Creative Stage}

In this stage, alternative ideas for drainage irrigation project began to emerge as a comparison of existing designs. Regarding the emergence of this alternative design is expected to create new design opportunities that can minimize the price. The alternative is conducted by making changes in the type of materials that will be expected to have a significant effect project on the price. On the project, the river stone installation is raised four alternatives included:

1) Alternative 1 using the river stone (existing).

2) Alternative 2 using K-225 conventional concrete.

3) Alternative 3 using cycloof K-175 concrete.

4) Alternative 4 using precast L-Shape K-300. 
Table 2

Strengthen and weaknesses of each alternative

\begin{tabular}{|c|c|c|c|}
\hline Alternative & Picture & Strengthen & Weaknesses \\
\hline $\begin{array}{l}\text { Alternative } \\
1 \text { using the } \\
\text { river stone }\end{array}$ & & $\begin{array}{l}\text { - Implementation is easy } \\
\text { - The implementation cost is } \\
\text { relatively cheaper }\end{array}$ & $\begin{array}{l}\text { - In certain areas of stone hard to be } \\
\text { obtained } \\
\text { - Bigger dimensions } \\
\text { - Many leaked due to hollow }\end{array}$ \\
\hline $\begin{array}{l}\text { Alternative } \\
2 \text { using K- } \\
225 \\
\text { convention } \\
\text { al concrete }\end{array}$ & & $\begin{array}{l}\text { - Strong structure. } \\
\text { - Low maintenance costs }\end{array}$ & $\begin{array}{l}\text { - Very strength tensile a weak } \\
\text { - Requires formwork } \\
\text { - Finishing is not tidy }\end{array}$ \\
\hline $\begin{array}{l}\text { Alternative } \\
3 \text { using } \\
\text { cycloof } \mathrm{K}- \\
175 \\
\text { concrete }\end{array}$ & & $\begin{array}{l}\text { - Mastering a solid concrete } \\
\text { structure } \\
\text { - Nonhigh maintenance cost }\end{array}$ & $\begin{array}{l}\text { - Mastering low tensile strength } \\
\text { - Requires formwork to hold concrete } \\
\text { - Finishing looks not straight/neat } \\
\text { - Requires plastering }\end{array}$ \\
\hline $\begin{array}{l}\text { Alternative } \\
4 \text { using } \\
\text { precast L- } \\
\text { Shape K- } \\
300\end{array}$ & & $\begin{array}{l}\text { - Quality guaranteed } \\
\text { - High weather resistance } \\
\text { level } \\
\text { - Efficiency of execution time } \\
\text { - Sleek design }\end{array}$ & $\begin{array}{l}\text { - Requires additional costs for } \\
\text { mobilization } \\
\text { - Must be put in a good place and } \\
\text { treated well } \\
\text { - Unexpectedly enough cost }\end{array}$ \\
\hline
\end{tabular}

\section{d) Analysis Stage}

The prior assessment process is conducted, it is necessary to prepare or give weight for each criterion. The order in ranking is sorted based on the questionnaire analysis results conducted. The ranking result is in the following table on a temporary weighting assessment.

Table 3

Temporary of ranking and weighting

\begin{tabular}{clccc}
\hline No & \multicolumn{1}{c}{ Functio } & Rate & Weight \% & Information \\
\hline 1 & Cost (A) & 7 & 25 & Highest priority \\
\hline 2 & Quality (B) & 6 & 21,43 & High Priority \\
\hline 3 & Implementation time (C) & 5 & 17,86 & High Priority \\
\hline 4 & Implementation method (D) & 4 & 14,29 & High Priority \\
\hline 5 & Mobilization (E) & 3 & 10,71 & High Priority \\
\hline 6 & Availability (F) & 2 & 7,14 & High Priority \\
\hline 7 & Aesthetics (G) & 1 & 3,57 & High Priority \\
\hline & Total ranking rate & 28 & 100 & \\
\hline
\end{tabular}

1) Assessment using zero-one method

At this stage, an assessment towards each alternative based on previously weighted criteria by using the zero-one method to obtain the index value of each alternative. Then, in determining the alternative assessment, it is necessary to arrange alternative preferences to make the assessment has a clear reference.

Sudiarsa, M., Sudiasa, W., \& Sutapa, K. (2018). Value Engineering Approach for Construction Materials Selection of Irrigation Drainage. International Journal Of Physical Sciences And Engineering (IJPSE), 2(1), 35-46. 


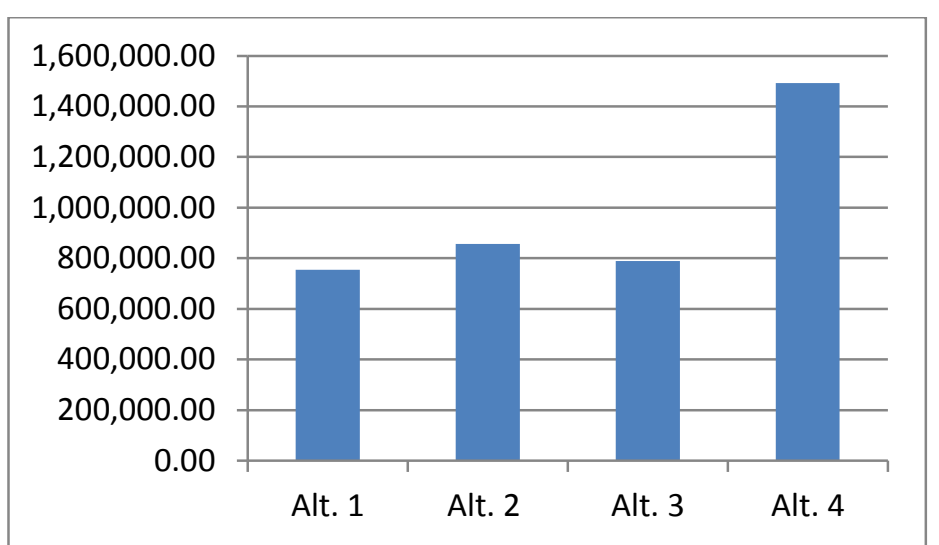

Figure 1. Cost comparison diagram

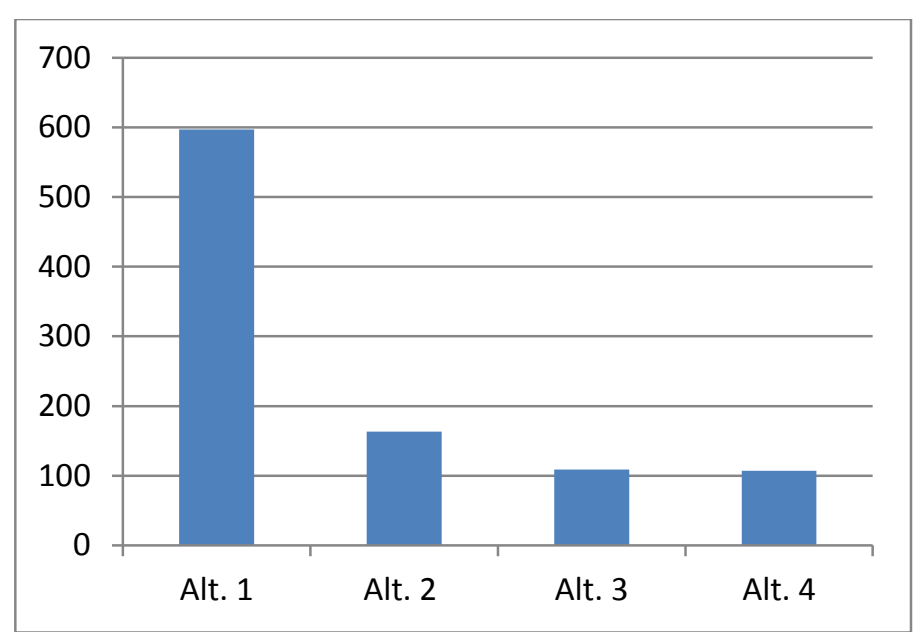

Figure 2. Comparison diagram of implementation time

Zero-one assessment towards cost-saving function. (A)

\begin{tabular}{ccccccc}
\hline Alternative & I & II & III & IV & Total & Index \\
\hline I & X & 1 & 1 & 1 & 3 & $1 / 2$ \\
\hline II & 0 & X & 0 & 1 & 1 & $1 / 6$ \\
\hline III & 0 & 1 & X & 1 & 2 & $1 / 3$ \\
\hline IV & 0 & 0 & 0 & $X$ & 0 & 0 \\
\hline \multicolumn{7}{l}{ Total } \\
\end{tabular}

Zero-one assessment towards quality function. (B)

\begin{tabular}{ccccccc}
\hline Alternative & I & II & III & IV & Total & Index \\
\hline I & X & 0 & 1 & 0 & 1 & $1 / 6$ \\
\hline II & 1 & X & 1 & 0 & 2 & $1 / 3$ \\
\hline III & 0 & 0 & $X$ & 0 & 0 & 0 \\
\hline IV & 1 & 1 & 1 & $X$ & 3 & $1 / 2$ \\
\hline \multicolumn{7}{c}{ Total } \\
\hline
\end{tabular}


Zero-one assessment of the implementation time function (C)

\begin{tabular}{|c|c|c|c|c|c|c|}
\hline Alternative & I & II & III & IV & Total & Index \\
\hline I & $\mathrm{X}$ & 0 & 0 & 0 & 0 & 0 \\
\hline II & 1 & $\mathrm{X}$ & 1 & 0 & 2 & $1 / 3$ \\
\hline III & 1 & 0 & $\mathrm{X}$ & 0 & 1 & $1 / 6$ \\
\hline IV & 1 & 1 & 1 & $\mathrm{X}$ & 3 & $1 / 2$ \\
\hline \multicolumn{5}{|c|}{ Total } & 6 & 1 \\
\hline
\end{tabular}

Zero-one assessment towards implementation method function. (D)

\begin{tabular}{|c|c|c|c|c|c|c|}
\hline Alternative & I & II & III & IV & Total & Index \\
\hline I & $\mathrm{X}$ & 0 & 0 & 0 & 0 & 0 \\
\hline II & 1 & $\mathrm{X}$ & 1 & 0 & 2 & $1 / 3$ \\
\hline III & 1 & 0 & $\mathrm{X}$ & 0 & 1 & $1 / 6$ \\
\hline IV & 1 & 1 & 1 & $\mathrm{X}$ & 3 & $1 / 2$ \\
\hline \multicolumn{5}{|c|}{ Total } & 6 & 1 \\
\hline
\end{tabular}

Preference for mobilization criteria. (E)

\begin{tabular}{|c|c|c|c|c|c|c|}
\hline Alternative & I & II & III & IV & Total & Index \\
\hline I & $\mathrm{X}$ & 0,5 & 0,5 & 0,5 & 1,5 & $1 / 5$ \\
\hline II & 0,5 & $\mathrm{X}$ & 0,5 & 0,5 & 1,5 & $1 / 5$ \\
\hline III & 0,5 & 0,5 & $X$ & 0,5 & 1,5 & $1 / 5$ \\
\hline IV & 1 & 1 & 1 & $\mathrm{X}$ & 3 & $2 / 5$ \\
\hline \multicolumn{5}{|c|}{ Total } & 7,5 & 1 \\
\hline
\end{tabular}

Zero-one assessment towards material availability function (F)

\begin{tabular}{|c|c|c|c|c|c|c|}
\hline Alternative & I & II & III & IV & Total & Index \\
\hline $\mathrm{I}$ & $X$ & 0,5 & 0,5 & 0,5 & 1,5 & $1 / 5$ \\
\hline II & 0,5 & $\mathrm{X}$ & 0,5 & 0,5 & 1,5 & $1 / 5$ \\
\hline III & 0,5 & 0,5 & $X$ & 0,5 & 1,5 & $1 / 5$ \\
\hline IV & 1 & 1 & 1 & $\mathrm{X}$ & 3 & $2 / 5$ \\
\hline \multicolumn{5}{|c|}{ Total } & 7,5 & 1 \\
\hline
\end{tabular}

Zero-one assessment towards aesthetic/appearance function. (G)

\begin{tabular}{|c|c|c|c|c|c|c|}
\hline Alternative & I & II & III & IV & Total & Index \\
\hline I & $\mathrm{X}$ & 1 & 1 & 0 & 2 & $1 / 3$ \\
\hline II & 0 & $\mathrm{X}$ & 0 & 0 & 0 & 0 \\
\hline III & 0 & 1 & $\mathrm{X}$ & 0 & 1 & $1 / 6$ \\
\hline IV & 1 & 1 & 1 & $\mathrm{X}$ & 3 & $1 / 2$ \\
\hline \multicolumn{5}{|c|}{ Total } & 6 & 1 \\
\hline
\end{tabular}

2) Final assessment of alternative and existing (weighting)

The weights and indices are known. Then, the next process is to perform the analysis using an evaluation matrix. Wherein, the matrix analysis multiplication is conducted between the weights of each criterion with each alternative assessment index that has been obtained. Then, each alternative summation can know which alternative has the highest value.

Based on the analysis results of evaluation matrix in Table 4, it can be seen that the alternative IV is using precast $L$ shape mastering the highest total weight superiority is $32.73 \%$. The weight value is obtained based on quality criteria, implementation time, implementation method, mobilization, material

Sudiarsa, M., Sudiasa, W., \& Sutapa, K. (2018). Value Engineering Approach for Construction Materials Selection of Irrigation Drainage. International Journal Of Physical Sciences And Engineering (IJPSE), 2(1), 35-46. 
availability, and aesthetics/appearance.

Table 4

Final assessment of alternatives and existing (weighting)

\begin{tabular}{|c|c|c|c|c|c|c|c|c|c|c|}
\hline \multirow{3}{*}{ No. } & \multirow{3}{*}{ Weight alternatives } & \multicolumn{7}{|c|}{ Criteria } & \multirow{3}{*}{$\begin{array}{c}\text { Total } \\
(\%)\end{array}$} & \multirow[b]{3}{*}{ Inf. } \\
\hline & & A & $\mathrm{B}$ & $\mathrm{C}$ & $\mathrm{D}$ & $\mathrm{E}$ & $\mathrm{F}$ & G & & \\
\hline & & 25 & 21,43 & 17,86 & 14,29 & 10,71 & 7,14 & 3,57 & & \\
\hline \multirow{2}{*}{1} & Alternative (I) & $1 / 2$ & $1 / 6$ & 0 & 0 & $1 / 5$ & $1 / 5$ & $1 / 3$ & \multirow{2}{*}{20,83} & Index \\
\hline & River stone & 12,5 & 3,57 & 0,00 & 0,00 & 2,14 & 1,43 & 1,19 & & Weight \\
\hline \multirow{2}{*}{2} & Alternative (II) & $1 / 6$ & $1 / 3$ & $1 / 3$ & $1 / 3$ & $1 / 5$ & $1 / 5$ & 0 & \multirow{2}{*}{26,78} & Index \\
\hline & Conventional concrete & 4,17 & 7,14 & 5,95 & 5,95 & 2,14 & 1,43 & 0,00 & & Weight \\
\hline \multirow{2}{*}{3} & Alternative (III) & $1 / 3$ & 0 & $1 / 6$ & $1 / 6$ & $1 / 5$ & $1 / 5$ & $1 / 6$ & \multirow{2}{*}{18,46} & Index \\
\hline & Concrete Cycloof & 8,33 & 0,00 & 2,98 & 2,98 & 2,14 & 1,43 & 0,60 & & Weight \\
\hline \multirow[b]{2}{*}{4} & Alternative (IV) & 0 & $1 / 2$ & $1 / 2$ & $1 / 2$ & $2 / 5$ & $2 / 5$ & $1 / 2$ & \multirow{2}{*}{32,73} & Index \\
\hline & Precats L Shape & 0,00 & 10,72 & 8,93 & 4,15 & 4,28 & 2,86 & 1,79 & & Weight \\
\hline
\end{tabular}

\section{e) Development Stage}

The development phase is closely related to Life Cycle Costing, including the initial cost, maintenance cost, and disposition cost (residual value).

Table 5

Life Cycle Cost

\begin{tabular}{lll}
\hline Description & Existing & L -Shape (selected alternative) \\
\hline Initial Cost & IDR. 2,990,814,742 & IDR. 5,917,542,753 \\
\hline $\begin{array}{l}\text { Maintenance cost } \\
\text { (5\% initial fee) }\end{array}$ & $\begin{array}{l}\text { IDR.149,540,737 } \\
\text { (every three years) }\end{array}$ & $\begin{array}{l}\text { IDR. 295,877,137 } \\
\text { (every ten years) }\end{array}$ \\
\hline $\begin{array}{l}\text { Residual value } \\
\text { (5\% initial fee) }\end{array}$ & 0 & IDR. 295,877,137 \\
\hline Age building plan & five years & twenty years \\
\hline Interest Rate & $12 \%$ & $12 \%$ \\
\hline
\end{tabular}

Table 6

Life cycle cost calculation for river stone

\begin{tabular}{cccr}
\hline Year to & Initial fee (IDR) & $(1+\mathrm{i})^{\mathrm{N}}$ & \multicolumn{1}{c}{ Value (IDR) } \\
\hline 0 & $2,990,814,742$ & 0 & $2,990,814,742$ \\
\hline 3 & $149,540,737$ & 1,41 & $210,852,439$ \\
\hline 5 & & 1,76 & $5,263,833,946$ \\
\hline 8 & 2,48 & $370,861,027$ \\
\hline 10 & 3,11 & $9,301,433,848$ \\
\hline 13 & 4,36 & $651,997,613$ \\
\hline 15 & 5,47 & $16,359,756,640$ \\
\hline 18 & 7,69 & $1,149,968,268$ \\
\hline & Total & $36,299,518,530$ \\
\hline
\end{tabular}


Table 7

Life Cycle Cost Calculation for Precast L Shape

\begin{tabular}{|c|c|c|c|}
\hline Description & Fee (IDR) & $(1+i)^{N}$ & Value (IDR) \\
\hline Initial Cost & $5,917,542,753$ & 0 & $5,917,542,753$ \\
\hline Maintenance cost $10^{\text {th }}$ & $295,877,137$ & 3,10 & $917,219,124$ \\
\hline Maintenance cost $20^{\text {th }}$ & $295,877,137$ & 9,65 & $2,855,214,372$ \\
\hline Residual value ( $5 \%$ initial fee) & $295,877,137$ & 9,65 & $2,855,214,372$ \\
\hline
\end{tabular}

Therefore, the amount of upcoming cost savings is:

$=$ Total overall river stone - total overall precast $L$ shape

$=$ IDR. 36,299,518,530 - IDR. 12,545,190,620

$=$ IDR. $23,754,327,910$ with a plan 20 years old

\section{f) Recommended Stage}

This stage is the final stage in doing value engineering that aims to provide recommendations for research that has been previously conducted. Before giving recommendations, as for the details of implementation cost and time of each alternative can be seen as follows. From the previous analysis using the zero-one method, it is recommended the best alternative for irrigation drainage project using precast $L$ shape based on the following considerations:

- Efficiency implementation time

- Quality guaranteed

- Material is easy to obtain

- Not require heavy equipment in material transportation process

- Aesthetics/neat appearance

- Not require a special implementation method

Implementing alternative IV (four) design, i.e., using precast $L$ shape can cost-saving analysis is issued with 20 years old plan that is equal to IDR. $23,754,327,910$. If it is compared with the use of river stone installation.

\section{Conclusions}

Based on the analysis results of Value Engineering that have been conducted on the project of DAS irrigation drainage improvement in Cengcengan River, Gianyar can be concluded as follows:

a) From 4 (four) alternatives analyzed, alternative IV (four) is the best alternative that is by using precast $L$ shape used in irrigation channel work by using the zero-one method.

b) Cost savings gained after replacing stone pairs with precast $L$ shape with 20 years old building plan is IDR. 23,754,327,910 with a time savings of precast $L$ shape assembly work for 490 days.

\section{Suggestions}

1. If in a project required value engineering analysis, the analysis should be done at the planning stage. Therefore, the optimum potential savings are obtained without reducing the project quality.

2. Before value engineering is applied to a project, a clear agreement should be made regarding the results shared to be obtained between the owner, the contractor, and the value engineering consultant.

3. For closer results, we need to add more criteria reviews and more alternatives.

\section{Acknowledgements}

We would like to thank I Wayan Suryasa and María Rodríguez Gámez as an editor for their valuable time and advice to complete this paper.

Sudiarsa, M., Sudiasa, W., \& Sutapa, K. (2018). Value Engineering Approach for Construction Materials Selection of Irrigation Drainage. International Journal Of Physical Sciences And Engineering (IJPSE), 2(1), 35-46. 


\section{References}

1. Akbar, M. I., Hasyim, M. H., \& Unas, S. E. (2014). Analisa Produktivitas Pemasangan Dinding Dengan Material M-panel (Studi Kasus: Watermark Hotel and Resort Di Bali). Jurnal Mahasiswa Jurusan Teknik Sipil, 1(3), pp-945.

View in (Google Scholar)

2. Barrie, D. S., \& Paulson, D. S. (1987). Manajemen Konstruksi Profesional. Penerbit Erlangga. View in (Google Scholar)

3. Castillo, G. A. L., Álava, L. A. C., Fernández, M. C., \& Llanes, M. V. (2017). Roadmap for the Introduction of Smart Grids in Ecuador. International Journal of Physical Sciences and Engineering (IJPSE), 1(2), 1-10. View in (Google Scholar)

4. Crum, L. W. (1971). Value engineering: the organised search for value. Longman. View in (Google Scholar)

5. De Calderero, R. P., Panchana, M. J. C., Lectong, D. M., \& Hernández, E. H. O. (2018). Use of Concrete Debris. International Journal of Physical Sciences and Engineering (IJPSE), 2(1), 1-12.

View in (Google Scholar)

6. Delgado, G. R. E., Meza, A. K. T., Chávez, S. A. R., \& Murillo, G. S. A. (2018). Demands of People with Disabilities and Empowerment of Resilient Strategies. International Research Journal of Management, IT and Social Sciences (IRJMIS), 5(1), 45-54.

View in (Google Scholar)

7. Hutabarat, J. (1995). Diktat Rekayasa Nilai. Malang: Institut Teknologi Nasional. View in (Google Scholar)

8. Jurado, W. C. C., Pérez, A. V. P., Quiroz, A. M. V., \& Gámez, M. R. (2017). Environmental Impact On Electrical Networks Near The Manabita Litoral. International Journal of Life Sciences (IJLS), 1(2), 18-27.

View in (Google Scholar)

9. Leung, M. Y., \& Liu, A. M. (2003). Analysis of value and project goal specificity in value management. Construction Management \& Economics, 21(1), 11-19.

View in (Google Scholar)

10. Listiono, A. (2011). Aplikasi value engineering terhadap struktur pelat dan balok pada proyek pembangunan gedung asrama putra SMP MTA Gemolong (Doctoral dissertation, Universitas Sebelas Maret). View in (Google Scholar)

11. Meza, A. K. T., Freyre, J. R. A., Cevallos, M. G. O., \& Pico, M. J. M. (2018). Autonomy, Good Humor and Support Networks, Potential of Community Resilience Intervention in People Victims of the Earthquake in the Calderón Parish. International Research Journal of Management, IT and Social Sciences (IRJMIS), 5(1), 1-8. View in (Google Scholar)

12. Mubin, A., \& alfarisi, S. peningkatan produktivitas dan kinerja lingkungan pada industri penyamakan kulit dengan menggunakan metode green productivity.

View in (Google Scholar)

13. Omer, A. M. (2017). Identifying, Developing, and Moving Sustainable Communities through Application of Bioenergy for Energy or Materials: Future Perspective through Energy Efficiency. International Journal of Life Sciences (IJLS), 1(1), 9-39.

View in (Google Scholar) 
14. Omer, A. M. (2017). Sustainable Development and Environmentally Friendly Energy Systems. International Journal of Physical Sciences and Engineering (IJPSE), 1(1), 1-39.

View in (Google Scholar)

15. Priyo, M., \& Hermawan, T. D. (2010). Aplikasi Value Engineering pada Proyek Konstruksi (Studi Kasus: Proyek Pembangunan Gedung BPKP Yogyakarta). Jurnal Semesta Teknika, 13(2), 116-129.

View in (Google Scholar)

16. Rosado, I. S. M., Ortega, J. M. P., Medranda, E. A., \& Basurto, E. X. C. (2018). Teaching Resilience to People with Visual Disabilities. International Research Journal of Management, IT and Social Sciences (IRJMIS), 5(1), 36-44.

View in (Google Scholar)

17. SINAGA, A. T. (2012). Analisis Perbandingan Biaya Dan Waktu Pekerjaan Dinding Menggunakan Pasangan Bata Merah Dan Bata Ringan Pada Proyek Bangunan Gedung Bertingkat (Doctoral dissertation, UAJY). View in (Google Scholar)

18. Soeharto, I. (1995). Manajemen Proyek: Dari konseptual sampai operasional. Jakarta: Erlangga. View in (Google Scholar)

19. Wisudawati, N. N. S., \& Maheswari, A. I. A. (2018). Potential of Silver Craft Product through to CommunityBased for Tourism Sustainability in Celuk Village. International Research Journal of Management, IT and Social Sciences (IRJMIS), 5(1), 9-15.

View in (Google Scholar)

Sudiarsa, M., Sudiasa, W., \& Sutapa, K. (2018). Value Engineering Approach for Construction Materials Selection of Irrigation Drainage. International Journal Of Physical Sciences And Engineering (IJPSE), 2(1), 35-46. doi:10.29332/ijpse.v2n1.89 


\section{Biography of Author}

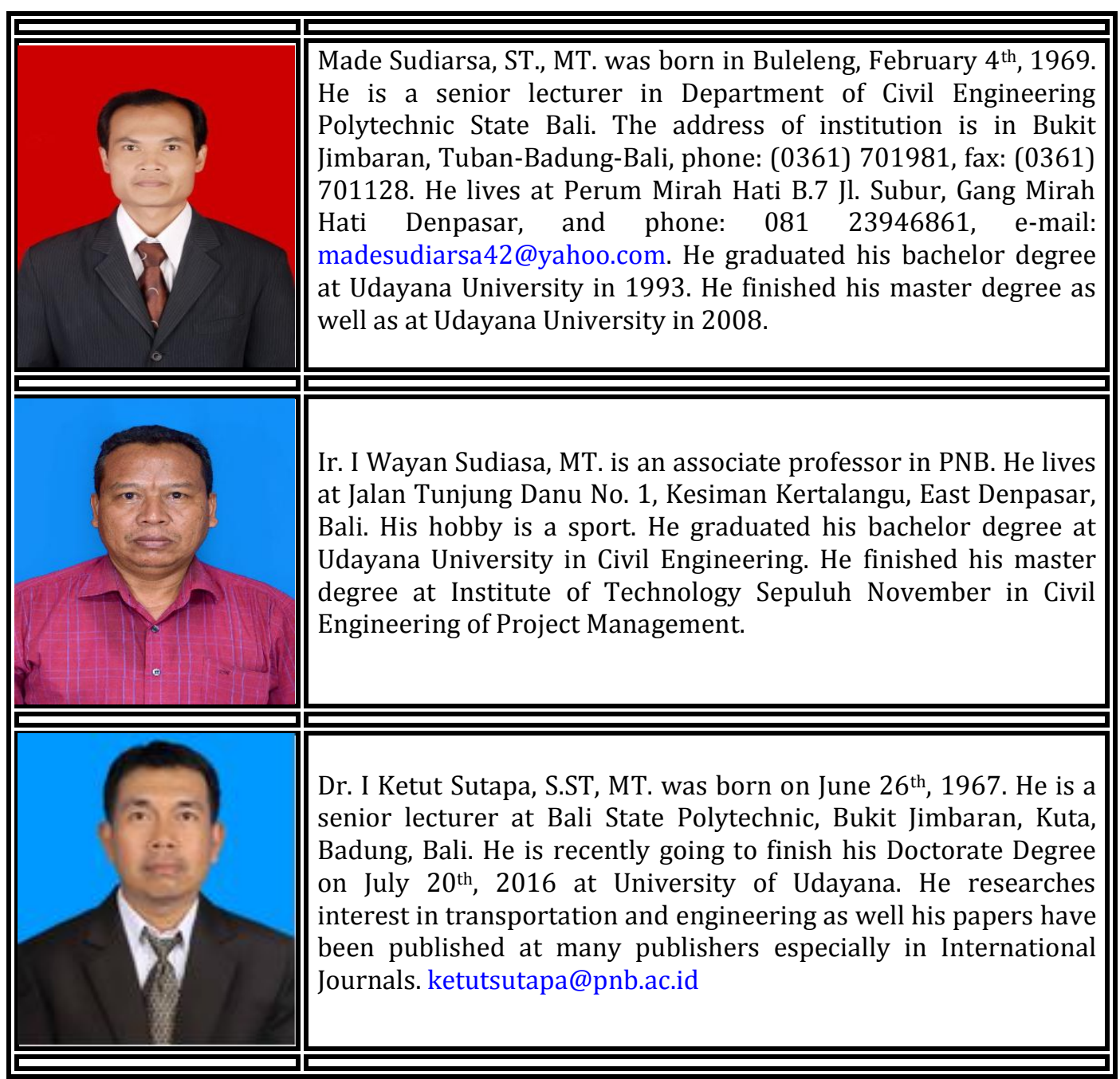

